Febianti Nurul Adha ${ }^{1}$, Moses Glorino Rumambo Pandin ${ }^{2}$

${ }^{1}$ Department of History, Faculty of Humanities, Airlangga University

${ }^{2}$ Department of English Literature, History, Faculty of Humanities, Airlangga University

Airlangga University - Campus B, Jl. Dharmawangsa Dalam, Airlangga, Gubeng District, Surabaya

City, East Java 60286

Email: ${ }^{1}$ febianti.nurul.adha-2020@ fib.unair.ac.id and ${ }^{2}$ moses.glorino@ fib.unair.ac.id

\title{
BOOK REVIEW: \\ MATINYA EPIDEMIOLOG: EKSPANSI MODAL DAN ASAL-USUL COVID-19 \\ (DEAD OF EPIDEMIOLOGY: CAPITAL EXPANSION AND ORIGIN OF COVID-19)
}

Title: Death of Epidemiologist: Capital Expansion and Origin of Covid-19; Author: Rob Wallace; Publisher: Independent Publisher; City of Publication: Yogyakarta; Publication Year: January 2020; Pages: 258 Pages; ISBN: 978-623-93362-7-1

\section{Book Review Introduction}

The book entitled "The Death of Epidemiologists: Capital Expansion and the Origin of Covid$19 "$ has a total of 258 pages with very dense content and many sources of writing. This book was written by Rob Wallace in 2020, then translated by A. Faricha Mantika and published by Independent Publishers the following year. Rob Wallace is an evolutionary biologist and public health phylogeography currently working as a researcher at the Institute for Global Studies at the University of Minnesota. Rob Wallace is also the author of Big Farms Make Big Flu, Dead Epidemiologist, and the soon-to-be-published Revolution Space, all three published by the Monthly Review Press. Based on the table of contents, the book contains 12 chapters, two of which are chapters 1 and 4 containing interviews conducted by Rob Wallace.

The purpose of writing the book is an attempt by the author to answer the main question, namely, how did the origin of covid-19? Furthermore, the writing of this book also aims to describe how the economic system causes the death of epidemiologists. Why is the denial and justification of the virus their way of the ruling class to exist? And why is it impossible for the ruling class to play a role in stopping this radical change and the virus? Therefore, the purpose of writing the book is to explain how the origin of the covid-19 virus and how epidemiologists submit and die by the expansion of capital belonging to the ruling class, as well as explain the political tools of "justification and denial" by the ruling class to maintain the status quo.

Writing a detailed book is suitable for those intellectuals who have a high curiosity. And also this book will be suitable for those who are interested in finding out about the origin of covid-19. Data is abundant and also new, which will help to answer questions about the virus. The book is also suitable for those who are interested in finding out about the relationship between the world economic system and public health. Rob Wallace provides an overview of how the economy has contributed to damaging the health of the earth's people. Then the book is also suitable for those who are interested in learning about the conditions of epidemiologists. Especially at the time, the virus attacked the earth. Not only focusing on covid-19, but Rob Wallace also described the conditions of epidemiologists and their handling of each new virus that infects the earth.

There a lot of information that can be obtained after reading the book "Death of Epidemiologists: Capital Expansion and the Origins of Covid-19". The book "Death of Epidemiologists: Capital Expansion and Origins of Covid-19" is rich in thoughts from intellectuals such as existential thinking, capitalism, Bordiue thought, Marx's thought, and others as material for analysis and reflection. In addition to thoughts, some data have been obtained through solid intellectual research. The most important of the contents of the book is the information regarding the relation of thought and the data contained in it, which provides accurate analysis and opens eyes to facts that may be for some people who are still unfamiliar.

Why is it important for us to review the book? The book provides a real and relatively easy-tounderstand picture of the current condition. Why is the handling of Covid-19 considered too late? Why does it seem as if this virus has not stopped until now? Why does the economic system seem to have no solidarity with this condition? Why is the upper class getting richer when the lower middle class is getting poorer? These questions will obtained after reading the book. The important point is there many 
statements in the book. For Example, why is it necessary to rebuild the legacy of "left" thinking to deal with the onslaught of the virus? Thus the book is important to review.

\section{Results of Reviews}

This book will meet the needs of its intended audience. As explained earlier, several categories of readers will read this book. Many things will be gained by the reader to answer questions about this book. In addition, the discussion is dense but easy enough to understand, which will make this book easy to meet the needs. For example, does COVID come from animals? These questions will be easily answered with books through accurate data and analysis. Thus the reader will feel his questions answered and fulfilled.

There is a lot of new information gained after reading this book. Some of this information is a term, analogy, or code for something that is often heard, but rarely for ordinary people or people who are not in the same field to know it. So when reading the book, the reader will look for the meaning of the term and explore its relationship. In addition, information will also be found from several studies that some readers may not know about. COVID-19 is an event that is happening at this time, a lot of research on the subject may have been overlooked.

After reading the book, readers will understand many of the facts they just learned. Critical thinking about major events such as this pandemic is increasing. Besides, readers will corner the prevailing economic system and those who are in the upper-middle class. Rob Wallace's vivid depiction makes an important impact, the facts spilled over will make the reader feel agree with him. Thus what influence the book has on the reader, is increasingly critical thinking.

From the book, the way Rob Wallace influences critical thinking in reading is by elaborating the evidence and facts. In addition, at the end of each chapter, Rob Wallace will provide a place where there are sentences that will contain his analysis and questions that will make the reader rethink what he has learned. In addition, in the book, several quotes will make the reader think again about the relationship between the quote and the chapter being read. And in the chapter where Rob Wallace conducts an interview, Rob Wallace several times uses an analogy that will quickly catch the meaning of the analogy.

The evidence in this book is very dense, marked by the number of footnotes that reach almost half a page on each page. The evidence displayed is evidence from studies, notes, journals, interviews, and quotes from several figures from various sources. From the calculation of the footnotes used, there are about 679 sources of evidence used for the writing of this book. In addition to this evidence, there a link connects to the Youtube application platform was found. It is known that the link is one example of an ad about agribusiness, which according to Rob Wallace can lead to new types of diseases.

Covid-19 cases have been rampant in the years between the end of 2019 and now. The evidence used by Rob Wallace is very convincing, Rob Wallace uses a lot of reference evidence sources in 20192020. There is some evidence that is below that year, but the evidence is used to build a relationship between viruses that have emerged and viruses that have just emerged. Thus the evidence supports the explanation in the book.

The book clearly describes the origins of covid, which is believed to have emerged from the Wuhan market in China, to be precise, the food market is quite extreme. Rob Wallace then gave an opinion on why people dig deeper into the forest and make these animals as food and livestock industry. Pathogens shouldn't surface, but people approaching themselves for the unusually capitalized food industry. Causes the worst pathogens that would otherwise die in the absence of a host again find new hosts and rapidly infect urban communities.

Epidemiologists try to give warnings, but the ruling class always has a different opinion. Instead of showing solidarity amid a pandemic, the ruling classes deny and justify and accuse other parties. What Rob Wallace calls "pandemic theater." Epidemiologists feel the unrest during an outbreak is a form of defeat deliberately disguised as heroism. Many of them are epidemiologists and public health experts who are funded to conduct research, erase the sin of the economic system that is causing chaos and rationalize the bad practices of commodification that are the cause of the emergence of deadly pandemics. So that, Rob Wallace called it the death of the epidemiologist. 
The book "Death of Epidemiologists: Capital Expansion and the Origins of Covid-19" uses an analytical description writing style. Rob Wallace wrote this book by describing the facts and evidence with a detailed analysis of the covid-19 virus and the influence of the ruling class on epidemiologists. In this book, there are several metaphors, terms, and analogous language that require more understanding. Writing is impersonal and uses scientific writing and grammar techniques. The structure of writing the book is by the purpose of writing. Regarding the flow of writing, some readers may feel that the plot is not quite right. However, it does not affect the meaning and purpose of writing. This book has a size of $14 \times 21 \mathrm{~cm}$ with a thickness of approximately $1.3 \mathrm{~cm}$. The size of the book is quite right, especially for readers who like to travel so they can read flexibly.

In the book, there are a few things Rob Wallace might have missed. The first is a study of how to realize communism, which is far from the system built in the Soviet Union but puts aside a bad societal stigma against communism. The explanation about this only focuses on some "left" thinking that is considered to make the system better. The second is about ecosocialism, in the book it is said that the best solution is to run a system called ecosocialism. However, the explanation of ecosocialism is minimal, if indeed ecosocialism is the goal of the message conveyed by this book. Thus it requires an explanation or study to strengthen the contents of the book.

The advantage of the book provides a specific understanding of covid-19. Both regarding its origins and an explanation of why covid-19 cannot be underestimated. In addition, this book also provides an overview of the dark side of the economic system on public health, for those who are interested in finding out about it. In addition, the suggestions and questions at the end of each chapter can open the critical thinking of the readers of this book.

As for the weakness of the book, for some readers, the many terms that are quite common will eliminate interest in reading this book. Then this book is to cornering the agribusiness actors and the lack of response from the agribusiness actors and the ruling class regarding this matter. The character that appears as a highlight of the ruling class in this book is only Donald Trump.

The reviewer of the book "Death of Epidemiologists: Capital Expansion and the Origins of Covid-19" provides suggestions on several studies that might have been overlooked for more explanation. The second suggestion is about writing that contains a lot of metaphors and terms that some of the readers may have difficulty understanding, which ultimately affects a reading interest in this book. Suggestions for the readers of this book are expected to be critical in responding to the contents of the book which may be considered sensitive, such as communism and the criticisms made by Rob Wallace regarding the fields mentioned in this book.

Febianti Nurul Adha and Moses Glorino Rumambo Pandin Universitas Airlangga

\section{REFERENCE}

1. Wallace R. Matinya Epidemiolog: Ekspansi Modal dan Asal-usul Covid-19. Yogyakarta: Penerbit Independen; 2021. 258 p.

\section{BOOK AUTHOR BIODATA}

Rob Wallace is an evolutionary biologist and public health phylogeography currently working as a researcher at the Institute for Global Studies at the University of Minnesota. Rob Wallace is also the author of Big Farms Make Big Flu, Dead Epidemiologist, and the soon-to-be-published Revolution Space, all three published by the Monthly Review Press. 